\section{Plant Factors for Irrigating Mixed Turfgrass and Shrub Landscapes in a Humid Environment}

\author{
Tim R. Pannkuk ${ }^{1}$
}

\begin{abstract}
AdDITIONAL INDEX wORDs. evapotranspiration, Stenotaphrum secundatum, Ligustrum japonicum, Ilex cornuta 'Burfordii Nana', Ilex vomitoria 'Nana', leachate, soil moisture
\end{abstract}

\begin{abstract}
SUMMARY. Landscape water conservation methods and techniques contribute to managing water resources. Use of reference evapotranspiration $\left(\mathrm{ET}_{\mathrm{o}}\right)$ data and landscape coefficients is one method that needs further development. Local $\mathrm{ET}_{\mathrm{o}}$ data and actual plant water use were used to calculate plant factors (PFs) for three model landscapes composed of mixtures of turfgrass and shrubs. Model landscapes using a sandy loam soil included st. augustinegrass (Stenotaphrum secundatum), privet (Ligustrum japonicum), dwarf burford holly (Ilex cornuta 'Burfordii Nana'), and dwarf yaupon holly (Ilex vomitoria 'Nana') at three ratios of turfgrass to shrub vegetative cover: 80:20,50:50, and 20:80. Soil was placed into inground lysimeters in a complete randomized block design with soil moisture sensors and a drainage system. Lysimeters were irrigated with a sprinkler system, and water was applied at a rate of $100 \%$ replacement of $\mathrm{ET}_{\mathrm{o}}$ minus precipitation. Lysimeter soil leachate was collected from the drainage system and quantified. After 2 years, the PF of 20:80 and 50:50 turfgrass/shrub combination were greater than the PF of the 80:20 combination. Plant factors for the 80:20, 50:50, and 20:80 turfgrass:shrub combinations were $0.68,0.97$, and 1.01 , respectively. There were no seasonal differences in PFs. Total growing season leachate depth over 2 years was 63.4, 30.7, and $12.6 \mathrm{~mm}$ for 80:20,50:50, and 20:80, respectively. Further work on PFs should include other plant combinations, and evaluation in other climatic zones.
\end{abstract}

A menity landscape water use continues to be a focus of conservation efforts across the United States (U.S. Environmental Protection Agency, 2014). Water purveyors and municipalities struggle with water salinity, population increases, and drought, which place considerable strain on water supplies (Metropolitan Water District of Southern California, 2014; Niemczynowicz, 1999; Toze, 2006). As fresh water becomes increasingly scarce in terms of meeting demand for it, methods of reducing demand for water will take an increasing precedence in municipal water management (Moss et al., 2013). Landscape water conservation methods and techniques using new technology or sciencebased principles will continue to contribute to managing water resources (Cabrera et al., 2013).

The benefits of having landscape plants in the built environment include noise reduction, erosion prevention, shade, increased property value, and aesthetic benefits (Frank, 2003). Turfgrasses have been shown to improve percolation of rainfall, urban heat

Department of Agricultural Sciences and Engineering Technology, P.O. Box 2088, Sam Houston State University, Huntsville, TX 77340

${ }^{1}$ Corresponding author. E-mail: pannkuk@shsu.edu. dissipation, and reduced fire hazard to structures (Beard and Green, 1994). Irrigation water needed in landscapes to supplement non-sufficient precipitation during the growing season is a well-documented and a substantial portion of municipal water use (Cabrera et al., 2013; Romero and Dukes, 2011; Runfola et al., 2013). A study by Mayer et al. (1999) found average outdoor water use across 12 geographically diverse American cities was $58 \%$ of total residential consumption. In central Florida, Haley et al. (2007) found $64 \%$ of residential water use was outdoors. That study was based upon 27 cooperating residential homes over a 30 -month period. The City of Phoenix estimates $45 \%$ of its potable water delivered to residents is used outdoors (City of Phoenix, 2011). Hermitte and
Mace (2012) documented indoor and outdoor residential water use for 259 Texas cities from 2004 through 2008. Their study determined on average $31 \%$ of residential water usage was outdoors.

The quantity of water used to irrigate a landscape may be influenced by several very broad factors. Spinti et al. (2004) found the amount of time a resident had spent in a desert climate influenced landscape irrigation habits. Those residents spending a shorter period of time in a desert were more likely to conserve water in their landscape. Use of an automatic sprinkler system in a landscape may have an impact on water quantity applied (Mayer et al., 1999). Mayer et al. (1999) and Runfola et al. (2013) determined total lawn area was a significant predictor of annual landscape water use providing a positive correlation. Landscapes in climates with higher average temperatures tend to use more irrigation water than landscapes with moderate temperatures (Breyer et al., 2012; Mayer et al., 1999). Landscape water use also tends to increase during warmer months of the year (Breyer et al., 2012; Kjelgren et al., 2000).

Landscape water conservation methods and techniques continue to gain acceptance in the United States. The Irvine Ranch Water District (Irvine, CA) created an increasing block structure to water pricing that reduced outdoor water consumption among its users by $50 \%$ (Desena, 1998). In 1995, a comprehensive water conservation education program was started by the Albuquerque, NM Water System to reduce per capita use. This program included time-of-day for watering restrictions, odd-even street address for watering days, and promotion of xeric plants. Time-of-day violations could be fined from $\$ 20$ up to $\$ 1000$. This program had reduced water use in 2004 by $34 \%$

\begin{tabular}{llll}
\hline $\begin{array}{l}\text { Units } \\
\text { To convert U.S. to SI, } \\
\text { multiply by }\end{array}$ & U.S. unit & SI unit & $\begin{array}{l}\text { To convert SI to U.S., } \\
\text { multiply by }\end{array}$ \\
\hline 100 & $\mathrm{bar}$ & $\mathrm{kPa}$ & 0.01 \\
0.3048 & $\mathrm{ft}$ & $\mathrm{m}$ & 3.2808 \\
0.0929 & $\mathrm{ft}^{2}$ & $\mathrm{~m}^{2}$ & 10.7639 \\
3.7854 & gal & $\mathrm{L}$ & 0.2642 \\
2.54 & inch(es) & $\mathrm{cm}$ & 0.3937 \\
25.4 & inch(es) & $\mathrm{mm}$ & 0.0394 \\
1.1209 & lb/acre & $\mathrm{kg} \cdot \mathrm{ha}^{-1}$ & 0.8922 \\
0.0254 & mil & $\mathrm{mm}$ & 39.3701
\end{tabular}


compared with 1995 figures (City of Albuquerque, 2014). The city of San Antonio, TX, has implemented a water conservation program over the previous 20 years which can be described as remarkable. Despite a $67 \%$ increase in population, San Antonio's current water use is very near to what the water use was in 1984 (Postel, 2011). Most of the San Antonio Water System Management Plan places emphasis in landscape irrigation, which include outreach education, time-of-day, and day-of-week irrigation. These programs provide fine examples for other municipalities to emulate and adapt. However, researchbased results and outreach education will still be needed for landscape water use efficiency and conservation in amenity landscapes. This may include smart-irrigation controllers, alternative water sources, use of native and adapted plants, and mixed landscape crop coefficients (Cabrera et al., 2013; McCready et al., 2009; Pannkuk et al., 2010; Parsons et al., 2010).

Landscape irrigation based on mixed species crop coefficients is an emerging area of water conservation based on climatological conditions. Crop coefficients for irrigation exist for most turfgrass species and a few woody ornamental species, but crop coefficient type irrigation information on amenity landscapes with mixtures of two plant types is quite limited (Pannkuk et al., 2010). Urban landscapes are a heterogeneous mosaic of plant types that are managed in patches (Stabler, 2008). Further studies are needed to provide refinement to a mixed species landscape coefficient suitable to specific regions (Cabrera et al., 2013). The American Society of Agricultural and Biological Engineers (ASABE) has recently defined mixed-species landscape water use normalized to reference evapotranspiration as plant factors, rather than crop coefficients (ASABE, 2012; Beeson et al., 2014; Sun et al., 2012a). The new S623 Standard attempts to define landscape water use requirements nationally across various humidity zones (Beeson et al., 2014).

The mixtures of plant forms in landscapes (grasses vs. woody plants) may also influence the amount of water entering soil and percolating downward to potentially recharge groundwater. Beard and Green (1994) summarized benefits of turfgrasses to groundwater recharge and surface water quality. Groundwater recharge is generally greater in areas of annual crops and grasses than it is in areas of trees and shrubs (Prych, 1998). Allison et al. (1990) demonstrated an impact of vegetation in Australia where deeprooted eucalyptus (Eucalyptus sp.) trees were replaced with shallowrooted crops resulting in recharge increases of about two orders of magnitude. Therefore, as recharge is evaluated, there is some dependence on land use/land cover. Irrigated areas contribute to water returned to soil for groundwater flow and may have a significant impact on recharge.

There is growing interest in use of $\mathrm{ET}_{\mathrm{o}}$ data from weather stations for irrigation recommendations in amenity landscapes. Therefore, objectives of this study were to determine PFs of model landscapes composed of mixed turfgrass and shrub species, and determine any seasonal effects on PFs. Second, as a result of irrigation in amenity landscapes with various plant forms, amounts of leachate were measured in each plant combination. Water percolating downward and potentially recharging groundwater in amenity landscapes has not been measured in previous work; therefore, this research would address this gap in literature.

\section{Materials and methods}

The experiment was conducted in Huntsville, TX, at the Sam Houston State University Plant Science Field Laboratory. Nine drainage lysimeters were constructed during Jan. to Mar. 2011 in an area which does not have trees within $260 \mathrm{ft}$. The surrounding vegetation was a mixture of grasses. Rectangular-shaped excavations $7 \times 4 \times 2 \mathrm{ft}$ (length $\times$ width $\times$ depth) were made in native soil to create each lysimeter. Each excavation was lined with a 45 -mil ethylene propylene diene monomer (EPDM) rubber pond liner. Gravel (0.375-inch diameter) was placed in the bottom to a depth of 2 inches. A polyvinyl chloride (PVC) pipe (0.5 inch i.d.) drainage system was embedded into the gravel layer. The PVC pipe system consisted of four horizontal pipes capped at one end. These horizontal pipes had 2-mm holes drilled every 6 inches on the bottom side to allow leachate to enter. As shown in Figure 1, these four pipes were joined through a manifold into a vertical riser pipe (30 inches). This PVC pipe system allowed vacuum evacuation of leachate during saturated conditions.

The A horizon material of a Falba fine sandy loam (fine, montmorillonitic, thermic Typic Albaqualfs) was systematically passed through a 0.4 -inch screen to remove roots and debris before being placed into each lysimeter. A 6-inch lift of soil was added and tamped to 4 inches. This process was continued until lysimeters were filled. Six soil moisture sensors (model 10HS; Decagon Devices, Pullman, WA) where placed at two locations in each lysimeter. Each location is 24 inches from edge of the short sides of the lysimeter (Fig. 1). At each location, a sensor was placed at 0 - to 8 -inch, 8 - to 16 -inch, and 16to 24 -inch depths. Sensor cables were routed to the outer edge of the lysimeter. From lysimeters, cables were below surface grade to a nearby data collection station. A datalogger (model 10X; Campbell Scientific, Logan, UT) coupled with model AM 16/32 multiplexers (Campbell Scientific) allowed volumetric soil moisture content measurements to be made and recorded hourly. A laptop computer with LoggerNet software (Campbell Scientific) was used to manually download data from the datalogger.

Lysimeters were irrigated with an in-ground automatic system. Irrigation spray heads (MP Rotator Series; Hunter Industries, San Marcos, CA) were installed at a $12-\mathrm{ft}$ triangular spacing. A water meter was installed to allow measurement of total applied water. A weather station was located $50 \mathrm{ft}$ from lysimeters sited in turfgrass. Weather station components include: datalogger, temperature/relative humidity probe, tipping-bucket rain gauge with 6-inch orifice, pyranometer with leveling base, and wind sentry set. Environmental data from the station was used to calculate both $\mathrm{ET}_{\mathrm{o}}$ using a modified PenmanMonteith equation (Food and Agriculture Organization of the United Nations, 1998). Irrigation was adjusted weekly to replace $100 \%$ of calculated $\left(\mathrm{ET}_{\mathrm{o}}\right)$ minus precipitation. During periods when irrigation water was required, water was applied 1 or $2 \mathrm{~d}$ per week. Irrigation remained off during winter seasons. Table 1 includes mean monthly actual $\mathrm{ET}_{\mathrm{o}}$ and precipitation, 
and historic precipitation rates during the experiment.

Plant combinations were arranged in a complete randomized block design with three blocks. Each plant combination consisted of turfgrass and woody ornamental shrubs based on vegetative coverage of the lysimeter surface. Plant combinations are defined in Table 2. Plant installation occurred on 12 May 2011 without disturbing sensors and sensor cables. St. augustinegrass was

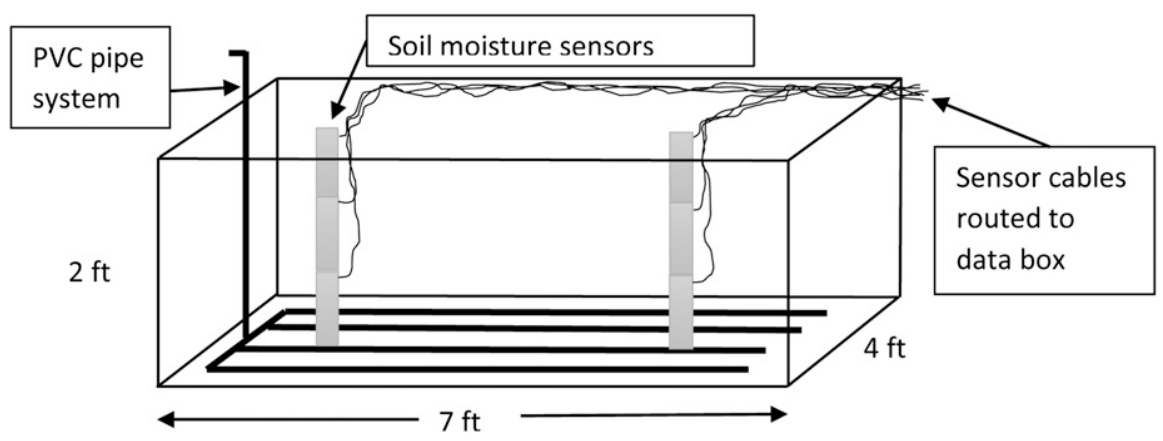

Fig. 1. Representation of an in-ground drainage lysimeter used for experiment involving three model landscapes in Huntsville, TX. Shown is the polyvinyl chloride (PVC) pipe system that is embedded in 2 inches $(5.1 \mathrm{~cm})$ of gravel for leachate evacuation, soil moisture sensors which measure volumetric water content of soil, and sensor cables routed to a nearby databox (datalogger) where soil moisture data are stored until downloaded. Changes in soil moisture over time (actual evapotranspiration) was used along with reference evapotranspiration to calculate plant factors. Not shown is the ethylene propylene diene monomer rubber pond liner that was placed into the square hole before filling with gravel and soil. Plant materials not shown; $1 \mathrm{ft}=0.3048 \mathrm{~m}$.

Table 1. Monthly actual reference evapotranspiration $\left(\mathrm{ET}_{\mathrm{o}}\right)$, monthly actual precipitation, and historic monthly precipitation at Huntsville, TX, during experiment to measure plant factors (PFs) among three model landscapes. Actual $\mathrm{ET}_{\mathrm{o}}$ and actual precipitation data taken from a weather station located $50 \mathrm{ft}$ $(15.2 \mathrm{~m})$ from experimental plots.

\begin{tabular}{lccc}
\hline & Actual ET $_{\mathbf{~}}$ & Actual precipitation & Historic precipitation \\
\cline { 2 - 4 } Mo. and yr & 5.99 & 0.98 & 4.17 \\
\hline Sept. 2011 & 3.81 & 2.08 & 4.69 \\
Oct. 2011 & 2.58 & 3.55 & 5.20 \\
Nov. 2011 & 1.67 & 3.94 & 4.13 \\
Dec. 2011 & 2.45 & 3.49 & 4.25 \\
Jan. 2012 & 2.36 & 6.38 & 3.35 \\
Feb. 2012 & 3.67 & 6.00 & 3.70 \\
Mar. 2012 & 4.97 & 1.21 & 3.27 \\
Apr. 2012 & 5.58 & 2.21 & 4.45 \\
May 2012 & 5.98 & 2.63 & 5.43 \\
June 2012 & 5.65 & 2.34 & 2.80 \\
July 2012 & 6.49 & 0.92 & 3.66 \\
Aug. 2012 & 4.72 & 5.46 & 4.17 \\
Sept. 2012 & 3.42 & 3.37 & 4.69 \\
Oct. 2012 & 2.41 & 0.02 & 5.20 \\
Nov. 2012 & 2.14 & 1.44 & 4.13 \\
Dec. 2012 & 2.06 & 3.44 & 4.25 \\
Jan. 2013 & 2.58 & 1.30 & 3.35 \\
Feb. 2013 & 4.34 & 1.34 & 3.70 \\
Mar. 2013 & 4.25 & 3.54 & 3.27 \\
Apr. 2013 & 5.49 & 6.41 & 4.45 \\
May 2013 & 6.35 & 2.45 & 5.43 \\
June 2013 & 6.00 & 1.21 & 2.80 \\
July 2013 & 6.23 & 0.64 & 3.66 \\
Aug. 2013 & & &
\end{tabular}

${ }^{2} 1$ inch $=25.4 \mathrm{~mm}$.

sod grown (All Seasons Turfgrass, Brookshire, TX) on a Katy fine-sandy loam (fine-loamy, siliceous, thermic Aquic Paleudalf). Woody plants were grown (Magnolia Gardens Nursery, Waller, TX) in a composted pine bark, and when planted, were placed in center of the lysimeter surface with turfgrass on either side. The soil surface beneath the shrubs remained bare throughout the study. A 4-month period was allowed for establishment. After these 4 months, each of the three plant combinations had green plant tissue (turfgrass and shrub) over 100\% of the plot surface area.

Turfgrass was maintained at 3 inches height, and trimmed biweekly to ensure percent coverage over the plot remained consistent (e.g., combination 1 was trimmed so turfgrass consistently covered only $80 \%$ of plot surface area). Shrubs were trimmed every 8-10 weeks, and each plot was maintained at a consistent canopy height throughout all treatments. Shrub count and surface area are in Table 2. Plots received granular fertilizers based on an annual soil test result from Texas Agrilife Soil, Water, and Forage Testing Laboratory recommendation for 'Raleigh' st. augustinegrass. A $13 \mathrm{~N}-0 \mathrm{P}-21.6 \mathrm{~K}$ (115 lb/acre) was applied spring, summer, and fall. A $0 \mathrm{~N}-0 \mathrm{P}-51.5 \mathrm{~K}$ (137 lb/acre) was applied each fall. Prilled limestone was applied (870 $\mathrm{lb} / \mathrm{acre}$ ) in Jan. 2012 for $\mathrm{pH}$ adjustment as recommended by the same soil test report. Fipronil was applied seasonally to control ants (Formica sp.). Azoxystrobin fungicide was applied in Sept. 2012 to the st. augustinegrass at the onset of mild brownpatch disease (Rhizoctonia solani). Brownpatch was not observed during Fall 2011. Glyphosate herbicide was applied every 4 to 8 weeks between plots for vegetation control.

Plant factors were determined by actual plant water use data (actual evapotranspiration) divided by $\mathrm{ET}_{\mathrm{O}}$ data during periods of time between precipitation events and/or irrigation (dry downs): Actual evapotranspiration $/ \mathrm{ET}_{\mathrm{O}}=\mathrm{PF}$.

Actual evapotranspiration was determined from changes in soil volumetric water content during a 2 - to $6-\mathrm{d}$ period soil dry down. Actual evapotranspiration measurements began 24 to $48 \mathrm{~h}$ after an irrigation or precipitation event. Reference evapotranspiration was determined for the 
same 2- to 6-d time period. Plant factors were grouped into early, mid, and late season (Table 3 ). PF calculations began in late season 2011 and concluded with midseason 2013.

Leachate from each lysimeter was evacuated and the volume measured every 1 to 2 weeks during the duration of the study. The leachate volume was converted to a leachate depth over plot surface area, and summarized by plant combination and season.

Plant combination PF values were analyzed by season over the 2 -year period. Mean leachate depth was analyzed by plant combination and season using analysis of variance (SAS version 9.3 for Windows; SAS Institute, Cary, NC). Leachate means are mean depth when evacuated from gravel layer of the lysimeter. Analysis of the randomized complete block design with a factorial structure that included plant combination and season used Scheffe's mean separation test to separate treatment means. Effects were considered significant at an alpha level of $P \leq 0.05$.

\section{Results}

Plant factors. Analysis of variance (ANOVA) indicated that plant combination $(P<0.0001)$ and season effects $(P<0.046)$ were significant. There was no significant difference in the interaction of plant combination and season. During the combined growing seasons (Sept. 2011-Sept. 2013), PFs for the 20:80 turfgrass and 50:50 turfgrass treatments were greater than the PF of 80:20 turfgrass treatment (Table 4). The PF for 80:20 was about $30 \%$ less than PFs of the two other plant combinations. Analysis of variance mean separation test did not discern differences among mean PFs seasonally. Seasonal PFs were $0.84,0.94$, and 0.87 for early, mid, and late season, respectively. Overall PF after 2 years was 0.89 . Drought stress and nutritional stress symptoms were not observed in plant materials during the experiment. New leaf blade extension in the st. augustinegrass began 10-15 Mar. each season indicating a return to active growth, and new leaf blade extension ceased 25-30 Nov. each season.

Leachate. Total leachate depth values are the sum of all leaching events presented over the 2 years and seasonally for each plant combination

Table 2. Turfgrass and shrub combinations of three model landscapes in which plant factors were measured in Huntsville, TX. Ratios indicate percent cover over the plot surface area by turfgrass:shrubs. Surface areas of shrub's canopies indicate areas occupied by shrubs in each plant combination.

\begin{tabular}{|c|c|c|c|c|}
\hline \multirow[b]{3}{*}{ Plant } & \multicolumn{4}{|c|}{ Turfgrass:shrubs (\% cover) } \\
\hline & $80: 20$ & $50: 50$ & $20: 80$ & \\
\hline & \multicolumn{3}{|c|}{ Plants (no.) } & Pot size ${ }^{z}$ \\
\hline St. augustinegrass & & & & Sod \\
\hline Privet & 1 & 2 & 4 & Number 3 \\
\hline Dwarf burford holly & 2 & 5 & 8 & Number 1 \\
\hline \multirow[t]{2}{*}{ Dwarf yaupon holly } & 1 & 4 & 6 & Number 1 \\
\hline & \multicolumn{4}{|c|}{$\left.-\mathrm{ft}^{2}\right)^{\mathrm{y}}-\mathrm{c}^{-}$} \\
\hline $\begin{array}{l}\text { Surface area of } \\
\text { shrub's canopies }\end{array}$ & 37.2 & 65.6 & 76.9 & \\
\hline Surface area of turfgrass & 22.4 & 14.0 & 5.7 & \\
\hline
\end{tabular}

${ }^{2}$ Number $1=0.7$ gal, number $3=2.7 \mathrm{gal} ; \mathrm{l}$ gal $=3.7854 \mathrm{~L}$.

${ }^{\mathrm{y}} 1 \mathrm{ft}^{2}=0.0929 \mathrm{~m}^{2}$.

Table 3. Timetable of experiment with calendar dates used in calculating early, mid, and late season plant factors among three model landscapes in Huntsville, TX. Data used in the experiment began 22 Sept. 2011 and ended 12 Sept. 2013.

\begin{tabular}{lccc}
\hline Season & 2011 & $\mathbf{2 0 1 2}$ & $\mathbf{2 0 1 3}$ \\
\hline Early & - & 12 April-24 May & 15 Mar.-20 May \\
Mid & - & 1 June-13 Sept. & 29 May-12 Sept. \\
Late & 22 Sept.-18 Nov. & 21 Sept.-7 Nov. & - \\
\hline
\end{tabular}

Table 4. The mean plant factors (PFs) of three model landscape plots by plant combination $(n=3)$, season $(n=9)$, and plant combination $\times$ season $(n=3)$ during the 2 years of the experiment in Huntsville, TX. Plant factors calculated as actual evapotranspiration divided by reference evapotranspiration during multiday soil drydown periods.

\begin{tabular}{lccc}
\hline & & PF & \\
\hline 20:80 Turfgrass:shrub & & $1.01 \mathrm{a}^{\mathrm{z}}$ & \\
50:50 Turfgrass:shrub & & $0.97 \mathrm{a}$ & \\
80:20 Turfgrass:shrub & & $0.68 \mathrm{~b}$ & \\
& Early & Mid & Late \\
\hline Seasonal mean & $0.84 \mathrm{Ns}^{\mathrm{z}}$ & 0.94 & 0.87 \\
& & & \\
& Early & Mid & Late \\
\hline 20:80 Turfgrass:shrub & $1.04 \mathrm{Ns}$ & $1.01 \mathrm{Ns}$ & $0.97 \mathrm{Ns}$ \\
50:50 Turfgrass:shrub & 0.88 & 1.05 & 0.98 \\
80:20 Turfgrass:shrub & 0.60 & 0.78 & 0.65 \\
\hline
\end{tabular}

${ }^{\mathrm{z}}$ Means followed by the same capital letter within column are not significantly different under Scheffe's mean separation test; NS = not significant.

(Table 5). Analysis of variance for mean leachate depth during the growing season was significant for both plant combination $(P<0.0001)$ and season $(P<0.0001)$. Plant combination by season interaction was not significant. As percent area covered by turfgrass increases, so did mean leachate depth (Table 5). Mean late season leachate depth was greater than early and midseason means. The late, mid, and early season leachate means were $1.3,0.3$, and $0.7 \mathrm{~mm}$, respectively. Total leachate depth of $80: 20$ turfgrass:shrub was about five times larger and two times larger when compared total leachate depths of the 50:50 and 20:80, respectively (Table 5). Seasonally, all three plant combinations yielded more total leachate depth in late season when compared with early or midseasonal depths. 
During winter seasons (late November to mid March) the irrigation was off, and leachate depth was analyzed separately. Analysis of variance model was significant with both plant combination and year contributing to variation. The winter mean leachate depth of 80:20 turfgrass:shrub was greater when compared with 20:80, but not greater than 50:50 turfgrass: shrub (Table 6). Total winter season leachate depth was greater in the first winter season when compared with the other 2 winter seasons (Table 6). The precipitation during this first winter of the experiment was $458 \mathrm{~mm}$ vs. 181 and $210 \mathrm{~mm}$ during second and third winter seasons (Fig. 2). Average precipitation during December to February is $301 \mathrm{~mm}$. However, mean winter leachate for 2011-12 was the same as 2013-14 and greater than 2012-13 (Table 6).

\section{Discussion}

Plant factors. Irrigation based on crop coefficients and $\mathrm{ET}_{\mathrm{o}}$ data has been quite valuable in resource management in food/feed/fiber crop production and in monoculture turfgrass systems. Research on its use in irrigation management of woody landscape plants or landscapes with mixed turfgrass/woody plants is limited. A study by Pannkuk et al. (2010) determined seasonal landscape plant factors ranging from 0.5 to 0.8 for a treatment composed of a single shumard oak (Quercus shumardii) and ornamental bunch grasses, muhly grass (Mublenbergia capillaries) and bluestem (Schizachyrium scoparium). The ornamental grasses in that study were cutback to 6-inch height each winter thereby removing most of the leaf surface area, and then remained untrimmed through the growing season. This varies from our study in which evergreen woody shrubs were trimmed to a consistent size through the year. Three of the treatments in the Pannkuk et al. (2010) study had one shumard oak per plot with the single shumard oak from a number 3 nursery container and a trunk diameter of 1.3 inches (Pannkuk, 2009). The leaf surface area of the tree was not reported. Those effects reported in the Pannkuk et al. (2010) study differ from our study in which landscape factors varied seasonally from 0.7 to 1.0. Plant density and surface area of the shrubs most likely contributed to the larger landscape

Table 5. Mean leachate depth during growing seasons for three model landscapes by plant combination and season, 2 year total leachate depth by plant combination, and seasonal leachate depths by plant combination during early, mid, and late seasons. Leachate was vacuumed from the gravel layer at bottom of drainage lysimeters used for calculating plant factors in Huntsville, TX.

\begin{tabular}{|c|c|c|c|c|c|}
\hline & \multirow{2}{*}{$\begin{array}{c}\text { Mean } \\
\text { leachate depth }\end{array}$} & \multirow{2}{*}{$\begin{array}{l}2 \text { yr total } \\
\text { depth }\end{array}$} & \multicolumn{3}{|c|}{ Seasonal depth } \\
\hline & & & Early & Mid & Late \\
\hline & 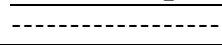 & $(\mathrm{mn}$ & $-\cdots$ & 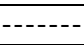 & ----- \\
\hline 20:80 Turfgrass:shrub & $0.3 c^{y}$ & 12.6 & 1.7 & 0.6 & 10.3 \\
\hline 50:50 Turfgrass:shrub & $0.6 \mathrm{~b}$ & 30.7 & 5.4 & 4.1 & 21.1 \\
\hline 80:20 Turfgrass:shrub & $1.3 \mathrm{a}$ & 63.4 & 14.7 & 15.7 & 33.0 \\
\hline Early season & $0.7 \mathrm{~b}$ & & & & \\
\hline Midseason & $0.3 \mathrm{~b}$ & & & & \\
\hline Late season & $1.3 \mathrm{a}$ & & & & \\
\hline
\end{tabular}

${ }^{\mathrm{z}} 1 \mathrm{~mm}=0.0394$ inch.

${ }^{y}$ Means followed by the same capital letter within column are not significantly different under Scheffe's mean separation test.

Table 6. Mean winter-season leachate depth for three model landscapes in Huntsville, TX, by plant combination and winter season, and total leachate depth during each winter season. Leachate was vacuumed from the gravel layer at bottom of drainage lysimeters used for model landscapes. Irrigation system was not operational during the winter season.

\begin{tabular}{lcccc}
\hline & \multirow{2}{*}{$\begin{array}{c}\text { Winter-season } \\
\text { mean depth }\end{array}$} & \multicolumn{2}{c}{ Total depth during winter } \\
\cline { 2 - 5 } & 2011-12 & $\mathbf{2 0 1 2 - 1 3}$ & $\mathbf{2 0 1 3 - 1 4}$ \\
\hline 20:80 Turfgrass:shrub & $2.0 \mathrm{~B}^{\mathrm{y}}$ & 44.6 & 0.0 & 8.6 \\
50:50 Turfgrass:shrub & $2.2 \mathrm{AB}$ & 39.3 & 6.5 & 12.5 \\
80:20 Turfgrass:shrub & $2.9 \mathrm{~A}$ & 42.3 & 12.5 & 20.4 \\
Winter 2011-12 & $2.8 \mathrm{~A}$ & & & \\
Winter 2012-13 & $1.3 \mathrm{~B}$ & & & \\
Winter 2013-14 & $2.3 \mathrm{~A}$ & & & \\
\hline
\end{tabular}

${ }^{\mathrm{z}} 1 \mathrm{~mm}=0.0394$ inch.

${ }^{y}$ Means followed by the same capital letter within column are not significantly different under Scheffe's mean separation test.

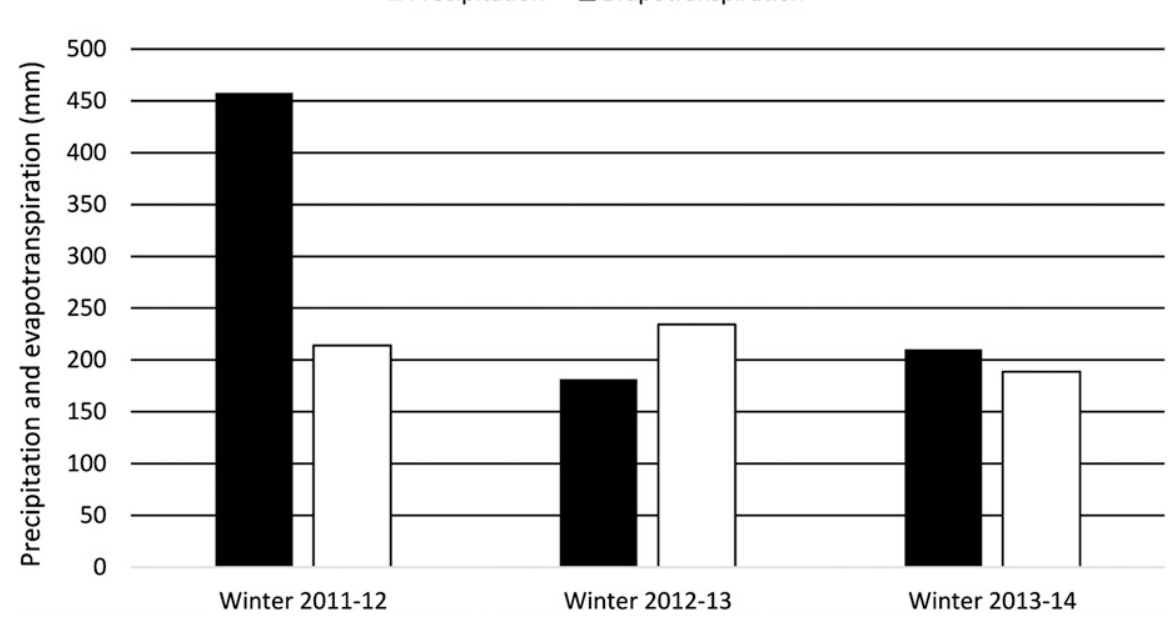

Fig. 2. Depth of precipitation and evapotranspiration during the winter seasons at Huntsville, TX. During the winter season, irrigation was shutoff for the three model landscapes and plant factors were not calculated; $1 \mathrm{~mm}=0.0394$ inch.

factors reported here. Sun et al. (2012a) reported mixed-species landscape factors ranged from 0.6 to 0.8 under well-watered conditions of their study that included deciduous and evergreen woody plants, herbaceous perennials, and turfgrass. That study suggested plant canopy cover, 
rather than plant material water use categorization, was the controlling factor in woody plant and perennial water use. Sun et al. also concludes that adjustments to percentage of landscape area covered by woody plants, perennials, and turf based on plant factor $\left(\mathrm{K}_{\mathrm{p}}\right)$ may be another method for conserving water in landscapes. The Sun et al. (2012a) study included plant treatments (turf, woody, and perennials) which varied in their canopy cover fraction. In our study, all three treatments had $100 \%$ cover, yet vary in woody plant density. The surface area of the shrubs in this study are $37.2,65.6$, and $76.9 \mathrm{ft}^{2}$ for the $80: 20$, 50:50, and 20:80 turf:shrub treatments, respectively. This corresponds to mean PFs over 2 years of $0.7,1.0$, and 1.0 , respectively.

Our study reveals greater surface area of plant cover due to plant density in a landscape contributes to differences in landscape water use and therefore PF. Amenity landscapes tend to be a mixture of plant forms from low growing two-dimensional turfgrass, to shrubs and trees which are more vertically oriented and threedimensional. More upright growing shrubs of this study have greater leaf surface area than that of turfgrass. Landscapes with a larger percentage of plants which are three-dimensionally oriented, more leaf transpiring area, may have larger PFs for this reason. Vapor pressure deficit (VPD), the difference between how much moisture is in the air and how much moisture the air can hold when saturated, is a driving force in transpiration. When daily high VPDs were averaged over the month, mean VPD during summer months were greater than $3.0 \mathrm{kPa}$ with the exception of July 2012 (Fig. 3). With treatments irrigated at $100 \%$ replacement of $\mathrm{ET}_{\mathrm{o}}$ minus rainfall, the plants were never exposed to soil moisture deficits and presumably no stomatal closure due to water stress. However, stomatal conductance was not measured. High VPD values appear to increase transpiration and subsequent PFs as shrub surface area increases in the model landscapes. The ANOVA table indicated a significant difference in main effect of season, but Scheffe's mean separation test did not discern a difference. A lack of significant difference by season may be partially due to evergreen shrubs being continually trimmed to a specified size
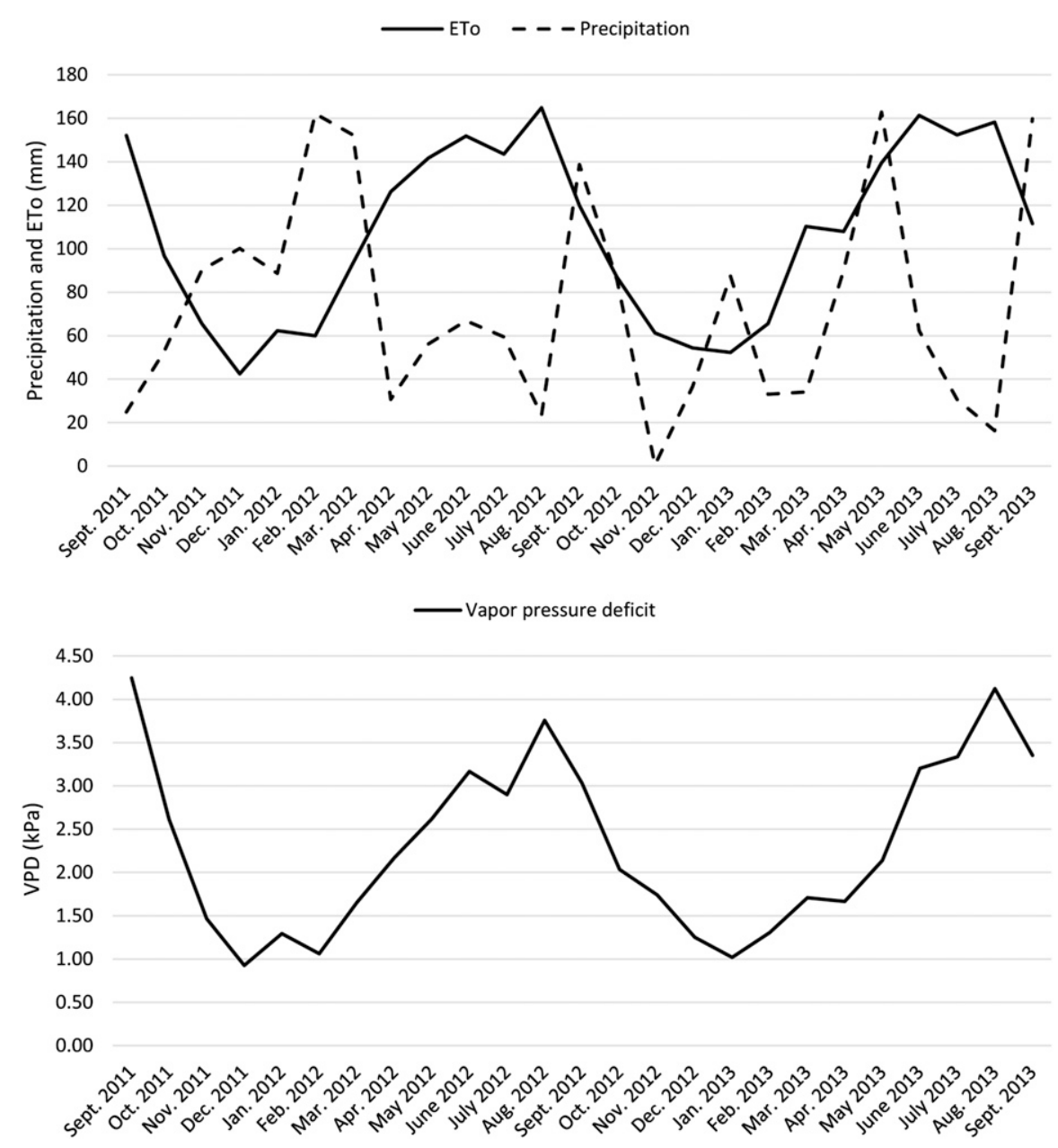

Fig. 3. Depth of monthly total evapotranspiration (ET $\mathrm{E}_{\mathrm{o}}$ ) and precipitation (top). Daily late-afternoon vapor pressure deficits averaged by month (bottom); vapor pressure deficit (VPD) is the difference between the amount of moisture in the air and how much moisture the air can hold when it is saturated. Data collected in Huntsville, TX, at site where plant factors of three model landscapes were measured; $1 \mathrm{~mm}=0.0394$ inch, $1 \mathrm{kPa}=0.01$ bar.

during the period of the experiment, and therefore similar water use compared with $\mathrm{ET}_{\mathrm{o}}$ during each of the three seasons. Pannkuk et al. (2010) documented seasonal differences among treatments when determining a landscape coefficient. However, in that experiment the plant palette included a small deciduous tree and ornamental bunch grasses which were only cutback each winter. That change in leaf canopy area, and ostensible seasonal growth, in tree and ornamental grasses probably contributed to a seasonal effect in observed landscape coefficient. Presence and combination of deciduous and evergreen plants in landscapes may therefore also influence seasonal water use and resulting $\mathrm{PF}$.

LANDSCAPE IRRIGATION. Most woody plants produced in nurseries have a confined root system from being grown in a container. Once these plants are established in a landscape, root systems of establishing shrubs and trees spread into the surrounding soil (Gilman and Beeson, 1996; Gilman and Kane, 1991). Depending on site conditions, woody plant root spread from the trunk may extend two to three times the dripline (Gilman, 2011). This implies that roots of plants in one irrigation zone may grow into the soil of a different irrigation zone. Potentially, soil in the amenity landscape can become a heterogeneous mix of plant roots after establishment. Zoning practices in irrigation management has largely ignored spread of plant roots outside of "their irrigation zone" over time. The concept of zoning in irrigation design and management is commonplace 
(Colorado State University, 2014; Florida-Friendly Landscaping, 2000; Texas A\&M Agrilife Extension, 2014). This study considered turfgrass and shrubs as one continuous irrigation zone since evidence indicates plant roots spread away from their crown and intermingle in the soil matrix (Gilman and Beeson, 1996; Gilman and Kane, 1991). Considering the mixture of roots from various plant types in soil of an established landscape, a PF which considers percentage of plant types (turfgrass, shrub, and tree) and plant density should be further studied. A plant type with the highest $\mathrm{PF}$ in an amenity landscape may have roots extending into the soil of other irrigated zones competing with other species for water. Turfgrass areas within an amenity landscape setting will likely have resource competing roots from nearby trees and shrubs, and vice versa. A review of the literature reveals there is a lack of science-based research whereby grouping plants into wateruse irrigation zones is evaluated based on plant form, root distribution through the soil, and actual plant water use.

This experiment used pop-up irrigation spray heads to irrigate lysimeters. In this irrigation method, some of the water is deposited on the plant tissue and evaporates. More threedimensionally shaped shrubs intercept more water than turfgrass in their canopy which in turn may evaporate. The usefulness of drip irrigation for shrubs in landscape water conservation is confirmed. However, use of spraytype irrigation equipment in amenity landscapes remains common (Kjelgren et al., 2000).

Leachate volumes. Efficient irrigation results in minimal deep percolation of water. Increased leaching during the growing season represents wasted water from the irrigator's perspective. In a well-watered landscape, this experiment demonstrates potential for deep percolation during the growing season which is considered wasted water. Irrigation water and precipitation caught in the canopy of the dense shrubs, and thereby evaporating back into the atmosphere, partially explains the lower volumes of leachate from treatments with greater density of shrubs.

Soil leachate depth results from this experiment suggest in those winters with less than average precipitation, landscapes with greater turfgrass cover will receive more water entering the root zone for soil percolation. It is noted that turfgrass entered dormancy in late November and remained dormant until early March based on new leaf blade extension. This finding also indicates more water evaporates and/or transpires from landscapes with greater woody plant canopy density during winter. Two-year cumulative leachate data suggests amenity landscapes containing greater woody plant density might reduce the amount of water percolating into soil and potentially recharge groundwater. Groundwater plays an important role in the ecological environment and in economic development. Therefore, investigation of dynamics of groundwater is important in the built environment. Sun et al. (2012b) found land use involving human activity is a driving factor in interception, infiltration capacity and surface evaporation. As humans continue to develop societies and economies, great changes occur on the land, and such changes can improve or degenerate water resources within a region (Garmendia et al., 2012).

This study was conducted in a warm humid region of North America with a limited number of woody plant species. The density of woody plants had impact on PF and amount of deep soil water percolation. More information is now available for use in landscape water conservation. More refinement of PFs is needed through testing with other combinations of plant species and plant density. Additional studies should also include designating lower coefficients (e.g., $0.5,0.6)$ and assessing plant quality over time. Precise irrigation of amenity landscapes is complex, and plant visual expectations are also variable among landscape managers. Society would also benefit from future studies which examine groundwater recharge quantity and quality in the built environment.

\section{Literature cited}

Allison, G.B., P.G. Cook, S.R. Barnett, G.R. Walker, I.D. Jolly, and M.W. Hughes. 1990. Land clearance and river salinisation in the western Murray Basin, Australia. J. Hydrol. (Amst.) 119:1-20.

American Society of Agricultural and Biological Engineers. 2012. ASABE to
Develop Standard for Determining Available Water for Irrigation Use. 11 July 2012. <http://www.asabe.org/media/ 90587/x623_pr.pdf>.

Beard, J.B. and R.L. Green. 1994. The role of turfgrasses in environmental protection and their benefits to humans. J. Environ. Qual. 23:452-460.

Beeson, R.C., D.R. Pittenger, B. Meecham, and R. Kjelgren. 2014. An overview of woody plants in ASABE Standard D623: Determining urban landscape plant water demand. HortScience 49:S265 (Abstr.).

Breyer, B., H. Chang, and G. Parandvash. 2012. Land-use, temperature, and singlefamily residential water use patterns in Portland, Oregon and Phoenix, Arizona. Appl. Geogr. 35:142-151.

Cabrera, R.I., K.L. Wagner, and B. Wherley. 2013. An evaluation of urban landscape water use in Texas. Texas Water J. 4:14-27.

City of Albuquerque. 2014. Conservation and Rebates. 9 June 2014. <http://www. abcwua.org/Conservation_and_Rebates. aspx>.

City of Phoenix Water Services Department. 2011. Water Resources Plan. 26 June 2014. <http://phoenix.gov/ webcms/groups/internet/@inter/ $@$ dept/@wsd/documents/web_content/ wsd2011wrp.pdf>.

Colorado State University. 2014. Watering Efficiently. I Nov. 2014. <http://www. ext.colostate.edu/mg/gardennotes/267. pdf $>$.

Desena, M. 1998. Irvine Ranch Water District uses rate structures to spur conservation. U.S. Water News 15:1-3.

Food and Agriculture Organization of the United Nations. 1998. Crop Evapotranspiration - Guidelines For Computing Crop Water Requirements. FAO Irr. Drainage Papers 56. 10 June 2014. <http://www.fao.org/docrep/X0490E/ x0490e06.htm>.

Florida-Friendly Landscaping. 2000. 9 FFL Principles. 1 Nov. 2014. <http://ffl. ifas.ufl.edu/homeowners/nine_principles. htm>.

Frank, M. 2003. The Benefits of Plants and Landscaping. 27 May 2014. <http://greenplantsforgreenbuildings. org/attachments/contentmanagers / 25 /BenefitofPlants.pdf>.

Garmendia, E., P. Mariel, I. Tamayo, I. Aizpuru, and A. Zabaleta. 2012. Assessing the effect of alternative land uses in the provision of water resources: Evidence and policy implications from southern Europe. Land Use Policy 29:761-770. 
Gilman, E.F. 2011. Where are the tree roots? Univ. Florida Ext. Bul. ENH137.

Gilman, E.F. and R.C. Beeson. 1996. Production method affects tree establishment in the landscape. J. Environ. Hort. $14: 81-87$.

Gilman, E.F. and M.E. Kane. 1991. Growth dynamics following planting of cultivars of Juniperus chinensis. J. Amer. Soc. Hort. Sci. 116:637-641.

Haley, M.B., M.D. Dukes, and G.L. Miller. 2007. Residential Irrigation water use in central Florida. J. Irrig. Drain. Eng. 133:427-434.

Hermitte, S.M. and R.E. Mace. 2012. The grass is always greener... Outdoor residential water use in Texas. Texas Water Dev. Board. Tech. Note 12-01.

Kjelgren, R., L. Rupp, and D. Kilgren. 2000 . Water conservation in urban landscapes. HortScience 35:1037-1040.

Mayer, P., W. DeOreo, E. Opitz, J. Kiefer, W. Davis, B. Dziegielewski, and J. Nelson. 1999. Residential end uses of water. Amer. Water Works Assn. Res. Foundation, Denver, CO.

McCready, M.S., G.L. Miller, and M.D. Dukes. 2009. Water conservation potential of smart irrigation controllers on st. augustinegrass. Agr. Water Mgt. 96:16231632.

Metropolitan Water District of Southern California. 2014. News Release: Heading into Hot, Dry Summer, Metropolitan Ramps up Conservation Call to Preserve Reserves During Drought. 27 May 2014. <http://www.mwdh2o.com/mwdh2o/ pages/news/press_releases/2014-05/ Ratching_Up_Conservation.pdf>.
Moss, J.Q., J.E. Haase, J.R. Vogel, T.A. Boyer, and D.L. Martin. 2013. Simple lawn irrigation measurement training for Master Gardeners and homeowners. J. Ext. 5l(3):3RIB7. 27 Mar. 2015. <http://www.joe.org/joe/2013june/ rb7.php>.

Niemczynowicz, J. 1999. Urban hydrology and water management-Present and future challenges. Urban Water 1:1-14.

Pannkuk, T.R. 2009. Evapotranspiration and leachate quality of warm-season turf and native grasses under different Texas landscape climates. Texas A\&M Univ., College Station, PhD Diss.

Pannkuk, T.R., R.H. White, K. Steinke, J.A. Aitkenhead-Peterson, D.R. Chalmers, and J.C. Thomas. 2010. Landscape $\mathrm{co}^{-}$ efficients for single- and mixed-species landscapes. HortScience 45:1529-1533.

Parsons, L.R., D.W. York, R. Holden, and B. Sheikh. 2010. Reclaimed water as an alternative water source for crop irrigation. HortScience 45:1626-1629.

Postel, S. 2011. Conservation in San Antonio is Saving More Than Water. 9 June 2014 <http://newswatch.nationalgeographic. $\mathrm{com} / 2011 / 07 / 14 /$ conservation-insan-antonio-is-savingmore-than-water $/>$.

Prych, E.A. 1998. Using chloride and chlorine-36 as soil-water tracers to estimate deep percolation at selected locations on the US Department of Energy Hanford Site, Washington. U.S. Geologic Survey Water-Supply Paper 2481:67.

Romero, C.C. and M.D. Dukes. 2011. Are landscapes over-irrigated in southwest
Florida? A spatial-temporal analysis of observed data. Irrig. Sci. 29:391-401.

Runfola, D.M., C. Polsky, C. Nicolson, N. Giner, R.G. Pontius, J. Krahe, and A. Decatur. 2013. A growing concern? Examining the influence of lawn size on residential water use in suburban Boston, MA. Landsc. Urban Plan. 119:113-123.

Spinti, J.E., R. St. Hilaire, and D. VanLeeuwen. 2004. Balancing landscape preferences and water conservation in a desert community. HortTechnology $14: 72-77$

Stabler, L.B. 2008. Management regimes affect woody plant productivity and water use efficiency in an urban desert ecosystem. Urban Ecosyst. 11:197-211.

Sun, H., K. Kopp, and R. Kjelgren. 2012a. Water-efficient urban landscapes: Integrating different water use categorizations and plant types. HortScience 47:254-263

Sun, Z., Q. Huang, C. Opp, T. Hennig, and U. Marold. 2012b. Impacts and implications of major changes caused by the Three Gorges Dam in the middle reaches of the Yangtze River, China. Water Resour. Mgt. 26:3367-3378.

Texas A\&M AgriLife Extension. 2014. Landscape Water Budgeting. I Nov. 2014. <http://agrilife.org/webcourses/2014/ $05 / 30 /$ landscape-water-budgeting/>.

Toze, S. 2006. Reuse of effluent waterBenefits and risks. Agr. Water Mgt. 80:147-159.

U.S. Environmental Protection Agency. 2014. WaterSense. 27 May 2014. <http://www.epa.gov/watersense/>. 